\title{
Author Index Volume 30 (2013)
}

(The issue number is given in front of the page numbers)

Ajegbomogun, F.O. and S.O. Popoola, Motivational strategies and utilisation of Internet resources as determinants of research productivity of lecturers in universities of agriculture in Nigeria

$(3,4) \quad 167-189$

Al Daoud, M., see Cox, A.M.

$(1,2) \quad 41-61$

Al-Khasawneh, A. and B.K. Hammad, Implementation of service learning and civic engagement for computer information systems students through a course project at the Hashemite University

$(3,4) \quad 191-203$

Cox, A.M., M. Al Daoud and S. Rudd, Information Management graduates' accounts of their employability: A case study from the University of Sheffield

$(1,2) \quad 41-61$

Hammad, B.K., see Al-Khasawneh, A.

Johnson, I.M., The impact on education for librarianship and information studies of the bologna process and related european commission programmes - and some outstanding issues in Europe and beyond

Mitchell, E., Reflective course construction: An analysis of student feedback and its role in curricular design

$(3,4) \quad 149-166$

Mutula, S.M., see Nyagowa, H.O.

$(1,2) \quad 93-115$

Nyagowa, H.O., D.N. Ocholla and S.M. Mutula, Service quality, user satisfaction and net-benefits' effect on e-School success: The case of NEPAD's e-School Pilot in Kenya

Ocholla, D.N., see Nyagowa, H.O.

$(1,2) \quad 93-115$

Oguz, F. and N. Poole, Who do you know? A study of connectedness in online education and employment

$(3,4) \quad 129-148$ 
Poole, N., see Oguz, F.

Popoola, S.O., see Ajegbomogun, F.O.

Rahim, N.F.A., Collaboration and knowledge sharing using 3D virtual world on Second Life

Rudd, S., see Cox, A.M.
$(3,4) \quad 129-148$

$(3,4) \quad 167-189$

$(1,2) \quad 1-40$

$(1,2) \quad 41-61$ 